\title{
The revealed preferences of high technology acquirers: An analysis of the innovation characteristics of their targets
}

\author{
Panos Desyllas and Alan Hughes*
}

\begin{abstract}
This paper investigates whether acquisitions involving public high technology firms are best understood in terms of acquirers taking over firms with 'superior' innovation performance to access their assets, or acquiring firms with 'inferior' innovation performance to turn them around. Innovation performance is proxied by R\&Dintensity (R\&D expenditure over assets), patent-intensity (patents per US \$million of assets), i.e. the R\&D productivity of a firm's assets, and the patent stock, i.e. the accumulated $\mathrm{R} \& \mathrm{D}$ output. We find substantial overlaps between target and nonacquired firm characteristics. Nevertheless targets have a relatively high R\&Dintensity and a large patent stock, which is consistent with acquirers targeting firms with a superior innovation performance. However, these targets have significantly lower pre-acquisition patent-intensity and hence a lower R\&D productivity. The targets are also experiencing weak financial performance. Our results are consistent with a selection process in which acquirers seek out firms that have a superior past innovation performance, but that are failing in terms of recent R\&D productivity and financial performance. A comparison of the performance of the targets with their acquirers reinforces this conclusion.
\end{abstract}

Key words: Mergers and acquisitions, Acquisition likelihood, R\&D, Patents FEL classifications: G34, O31, L20

\section{Introduction}

Preferences and motives driving actions are frequently not directly observable. Researchers might, however, be able to elicit them from observing the behaviour of the organisations in which they are formed. In this paper we attempt to infer the acquisition motives of high

Manuscript received 30 April 2007; final version received 18 November 2008.

Address for correspondence: Panos Desyllas, Manchester Business School, Booth Street West, Manchester M15 6PB, UK; email: pdesyllas@gmail.com

* Manchester Business School, University of Manchester, and Centre for Business Research (CBR) and Judge Business School, University of Cambridge, respectively. The authors gratefully acknowledge financial support from the ESRC/EPSRC, under the AIM initiative, and the CBR core grant. They are grateful to Mari Sako, Dennis Mueller, Jaideep Prabhu, to the anonymous referees of the CBR working paper series and the CJE and to the participants at the Oxford Intellectual Property Research Centre seminar and EURAM 2005 conference for helpful comments.

(C) The Author 2009. Published by Oxford University Press on behalf of the Cambridge Political Economy Society. All rights reserved. 


\section{2 of 23 P. Desyllas and A. Hughes}

technology acquirers by analysing their revealed preferences in terms of the companies they acquire. ${ }^{1}$ For this purpose, we investigate the characteristics of the firms acquired in acquisitions involving publicly traded high technology firms and we ask whether this group of acquisitions are best understood in terms of two alternative innovation-centred explanations.

The first explanation we call 'the search for superiority', according to which acquirers are motivated by the objective of acquiring firms with superior innovation performance relative to their industry counterparts. This explanation draws upon the resource-based view of the firm (Barney, 1986, 1991; Dierickx and Cool, 1989; Penrose, 1959; Wernerfelt, 1984), and implies that acquisitions have a value creation potential for acquirers by permitting them to internalise valuable external resources and capabilities. It is also consistent with Blonigen and Taylor's (2000) finding that electronic and electrical equipment firms used acquisition as a substitute for in-house research and development (R\&D). In fact, Blonigen and Taylor stress the importance of research to uncover targets' innovative characteristics to fully understand their finding that acquirers have a significantly lower R\&D activity.

The second explanation we call 'the search for inferiority', according to which acquirers are motivated by the objective of acquiring firms with inferior innovation performance, relative to both their industry counterparts and their acquirers, in order to turn them around. This explanation has its origins in the traditional market for corporate control theory, which states that competition in product and capital markets ensures that poor performers in economic or stock market terms will be eliminated from the market place (Manne, 1965; Singh, 1975, 1992). It is, however, taken forward from its standard form in the economics literature by being grounded in an interpretation focussing on high technology sectors and innovation-related firm attributes.

This paper contributes to our understanding of the acquisition phenomenon by integrating two different streams of earlier work on acquisitions. On the one hand, a number of management studies argue and find supportive evidence for the view that high technology firms rely heavily on the acquisition of entrepreneurial start-ups and spin-offs to source technological knowledge externally (Desyllas and Hughes, 2008; Dushnitsky and Lenox, 2005; Granstrand and Sjolander, 1990; Puranam et al., 2003). Although this view seems reasonable on the basis of behavioural and other advantages of small entrepreneurial firms in the innovation process (e.g. Williamson, 1975; Zenger, 1994), there is no evidence for the validity of this claim for acquisitions of relatively large publicly traded targets.

On the other hand, several economics studies that analyse the incidence of acquisition employ samples of publicly traded targets and focus on target financial characteristics and share price returns (Agrawal and Jaffe, 2003; Ambrose and Megginson, 1992; Dickerson et al., 2002, 2003; Hasbrouck, 1985; Hughes, 1993; McConnell and Martin, 1991; Morck et al., 1988; Palepu, 1986; Powell, 1997). A number of these studies aim at testing the validity of the market for corporate control hypothesis. However, they do not account for target innovative characteristics. Only Hall (1999) includes these in her investigation of target characteristics their R\&D-intensity (stock of R\&D over assets), but she employs

${ }^{1}$ This paper is not concerned per se with the motives of the owners of the target company for selling out to the bidder. A bid will be accepted where the shareholders believe that the price they are offered for their shares yields a value higher than they expect to get by retaining them. We instead use target characteristics to reveal the normative preferences of the firms who buy them. For a recent review of the circumstances under which the normative preferences of buyers are reflected in their revealed preferences see Beshears et al. (2008) and for a recent application in the finance literature see Philippon (2004). 
a sample from a wide cross-section of manufacturing US acquisitions during the period 1976-1986. Using aggregate data from a wide cross-section of industries might mask a differing relationship between acquisitions and innovative activity that is likely to hold between high-tech and non-high-tech firms. Moreover, R\&D alone ignores efficiency considerations, as it does not tell us anything about how successfully a firm transforms each dollar spent on $\mathrm{R} \& \mathrm{D}$ into new inventions. However, in her paper, Hall also refers to Addanki's (1986) unpublished doctorate thesis where, using a sample of 116 acquisitions by high technology US public firms from 1977 to 1984, he finds that firms that do R\&D but have no or a few patents are likely to be acquisition targets.

In this paper we address these gaps in previous research and focus on the comparative innovation characteristics of targets in acquisitions involving publicly traded high technology firms. We compare the innovation performance of targets with non-acquired firms and support this with a comparison of targets with their acquirers. Innovation performance is assessed in terms of a firm's $R \& D$-intensity (measured by the ratio of $R \& D$ expenditure to total assets), its patent-intensity (measured by successful patent applications per US $\$$ million of total assets), which we interpret as the R\&D productivity of a firm's assets, and its patent stock (calculated using the perpetual inventory formula), which we interpret as the accumulated output of a firm's R\&D. The analysis is conducted on the basis of a large sample of high technology acquisitions during the period from 1984 to 1998 in the USA.

Although our analysis shows that there is a large overlap in the $\mathrm{R} \& \mathrm{D}$, patenting and financial performance characteristics between targets and non-acquired companies, some significant differences between these groups are nonetheless present. Our results show that targets are, compared with non-acquired firms, performing relatively well in terms of R\&D-intensity. They also show that targets have a relatively large patent stock. However, compared with non-acquired firms, targets are more likely to have a zero or low preacquisition patent-intensity. We also find that targets tend to be somewhat larger than nonacquired firms, and that they are relatively more likely to experience poor profitability and low liquidity in the immediate pre-bid period. In sum, compared with non-acquired companies, the targets are experiencing short-term financial and patent-intensity performance but have relatively good $\mathrm{R} \& \mathrm{D}$-intensity and patent stock characteristics. When we compare targets with their acquirers we find that targets have comparable R\&D-intensity to their acquirers, but a significantly smaller patent stock and lower patent-intensity. They also appear to be growing at a slower pace, to have poor growth prospects and to be less profitable. The comparative financial and growth characteristics of targets, of acquirers and of non-acquired firms are consistent with previous studies of the market for corporate control. These suggest weak discrimination (substantial overlaps between these groups) but with some evidence of short run underperformance attracting takeover bids (see, in particular, Cosh and Hughes, 2008; Dickerson et al., 2002, 2003; Hughes, 1993; Singh, 1975). In relation to innovation indicators, however, the picture is more nuanced. Once again there is substantial overlap in innovation characteristics between the groups, but targets nonetheless have a good past record in terms of R\&D-intensity and patent stock compared with other potential targets. In that sense they are superior rather than inferior performers. However, they are experiencing short-term weaknesses in terms of their patent-intensity, which is consistent with a selection process similar to that revealed by the financial performance of these firms.

The remainder of this paper is organised as follows. The next section develops the theoretical background of this study. Section 3 describes the data and the methodology 


\section{4 of 23 P. Desyllas and A. Hughes}

employed. Section 4 presents the empirical results from the analysis. Finally, Section 5 summarises the main findings and presents the conclusions that can be drawn from the analysis of the paper.

\section{Theoretical background}

The average characteristics of large samples of acquisitions represent the aggregation of very different motives and outcomes (Hughes et al., 1980; Bower, 2001; Mueller, 2003) and explanations for their rationale may encompass various individual motivations and the outcomes associated with them. Our concern here is not to mount a uni-causal model of acquisitions, which rules out variations in motivations. Instead it is to analyse, in the particular case of innovation-related characteristics grounded in high technology industries, whether the acquisition phenomenon in aggregate is best understood in terms of one of two alternative explanations. These explanations, which we term the search for superiority and the search for inferiority, respectively, have roots in two rather distinct literatures, which we discuss in the next section.

\subsection{The search for superiority}

Since Penrose's (1959) seminal contribution, the academic debate about the sources of a firm's competitive advantage has largely concentrated on the role of the resources and capabilities it possesses (Barney, 1986, 1991; Dierickx and Cool, 1989; Wernerfelt, 1984). The resource-based view of the firm explains sustainable competitive advantages and economic rents on the basis of sustainable heterogeneities across firms in resources and capabilities that are rare, non-imitable and non-substitutable. Heterogeneities cannot be reversed in the short-run because strategic resources and capabilities cannot be bought in open markets, their internal accumulation requires time and it is hampered by path dependencies (Barney, 1986; Dierickx and Cool, 1989; Teece et al., 1997). Under this perspective, an acquisition strategy can be used to access other firms' resources and capabilities for the purpose of garnering otherwise unavailable competitive advantages and values to the firm. In knowledge-intensive high technology industries in particular, where knowledge has been identified as the most important strategic resource (Grant, 1996; Kogut and Zander, 1992), the acquisition of technological knowledge is likely to be a prime acquisition motive.

An acquisition can also be the preferred strategy for developing new knowledge because it is likely that with the ongoing exploitation of a firm's technology base, technological exhaustion occurs from the combination of existing forms of knowledge (Fleming, 2001; Kim and Kogut, 1996). It is argued that acquisitions can be employed as a means of technological renewal and of revitalising the knowledge base of the firm (Capron and Mitchell, 1998; Vermeulen and Barkema, 2001).

Even in cases where the desired resources or capabilities can be developed internally, acquisitions can be the preferred strategy representing a less risky and faster way of exploiting commercially viable innovation-related assets (Chakrabarti et al., 1994; Francis and Smith, 1995). Without overlooking the post-acquisition integration difficulties (Haspeslagh and Jemison, 1991; Puranam et al., 2003), if successfully completed, an acquisition can be seen as a less risky strategy, as some uncertainty inherent in the innovation process is resolved before the acquisition time (Arrow, 1962; Pavitt, 2005). An acquisition-intensive strategy can then be understood in a real option framework (Dixit and Pindyck, 1994). The decision not to invest in risky R\&D projects is the equivalent of 
getting the right to acquire the winner in an innovation race after uncertainty has been resolved. Also, acquisitions have the advantage that acquired companies have track records that can be analysed to make financial projections for future costs and expected performance (Hitt et al., 1996). An acquisition is a faster strategy when in-house R\&D and the commercialisation of its output require complementary assets that a firm does not possess (Teece, 1986), or when the target is further along the learning curve of a particular knowledge field. The time advantages of acquisitions are confirmed by Danzon et al. (2004), who find evidence that acquisitions are employed by pharmaceutical firms as a quick reaction to short-falls in their $\mathrm{R} \& \mathrm{D}$ pipeline.

The common element in these approaches is the idea that acquirers will seek out opportunities to improve or overcome shortcomings in their own performance and innovative capacity by seeking targets with superior knowledge or performance, or will try to avoid risky in-house investment in $R \& D$ by acquiring firms which have successfully completed innovation programmes and represent the winners of innovation races. Thus acquired or target firms should, when compared with other non-targeted firms, demonstrate superior innovation performance in terms of R\&D- and patent-intensity and patent stocks.

\subsection{The search for inferiority}

We focus here on the theory of the market for corporate control, which is one of the most frequently cited approaches in the economics literature on acquisitions.

The market for corporate control theory, first developed by Manne (1965), states that in the absence of effective competition in product markets inefficient firms will be eliminated by the transfer of the control of their assets to superior managers via takeover and merger (Singh, 1975, 1992). The market for corporate control is thus viewed as an arena in which managerial teams compete for the rights to manage corporate assets ensuring that assets are shifted to their most efficient uses or management (Jensen and Ruback, 1983; Jensen, 1986). ${ }^{1}$ Our focus on acquisitions in high technology industries and the link between innovation and economic performance in them (Cosh et al., 1996; Franko, 1989; Geroski et al., 1993) leads us to recast this approach in terms of the dynamic efficiency of firms measured by their innovative performance rather than their technical efficiency, which is typically captured in the market for corporate control literature by measures of financial returns. From an innovation perspective the market for corporate control should work to transfer control from poor innovation performers to superior innovation performers. ${ }^{2}$

\footnotetext{
${ }^{1}$ For an example of a related but separate approach that argues that firms with excess resources and management skills buy weaker firms and then use the acquirer's excess resources and skills to improve the performance of the target see Jensen and Ruback (1983), Capron and Mitchell (1998), Mueller and Sirower (2003). In a similar vein Morck and Yeung (1992) argue that certain assets, and particularly intangible assets such as technical knowledge, are better exploited by acquisition to 'internalise' the activity inhibiting either firm contracting because of market failures as well as the potential for spreading fixed costs over a larger scale. Such firms will prefer an acquisition to greenfield expansion either in cases when the required assets are socially embedded or when there is an underexploited innovation potential in target firms, which is reflected in their financial and stock market performance. In the later case, the firms wishing to expand will compare the costs of acquiring the assets they need through de novo investment and the costs of acquiring these assets already in place (Hasbrouck, 1985). Therefore, inefficient targets will be viewed by their acquirers as 'bargains' (Palepu, 1986; Powell, 1997).

2 Poor innovation performance in terms of new product or process introduction may arise for a number of reasons, such as under- or over-investment in $\mathrm{R} \& \mathrm{D}$, failure to direct research to the appropriate area, illchosen research projects, inadequate or inappropriate human or physical capital, or management of projects, or simply from the inherent risk of technical failure in innovation programmes.
} 


\section{6 of 23 P. Desyllas and A. Hughes}

Thus acquired or target firms should, when compared with other non-targeted firms, be characterised by poor innovation performance in terms of R\&D- and patent-intensity and patent stocks.

\section{Methods}

\subsection{The dataset}

Acquisitions are defined as deals where the acquiring firm owns less than $50 \%$ of the target's voting shares before the acquisition and as a result of the acquisition increases its ownership to at least $50 \%$. Our sample consists of high technology acquisitions, which are deals involving acquirers with some part of their activity in one of the high-tech industries as specified by Hall and Vopel (1996) and both the acquiring and the acquired firms have their primary activity in SIC 28 Chemicals and Allied Products, SIC 35 Industrial and Commercial Machinery and Computer Equipment, SIC 36 Electronics and Electrical Equipment, SIC 37 Transportation Equipment, SIC 38 Measuring, Analyzing and Controlling Instruments; Photographic, Medical and Optical Goods, SIC 48 Communications, SIC 73 Business Services or SIC 87 Engineering, Accounting, Research, Management and Related Services. ${ }^{1}$ We focus on acquisitions involving publicly traded firms where the targets are incorporated in the USA. We draw our analysis samples of targets from a 'population' of 829 completed acquisitions with a combined value in excess of a half of a trillion dollars that were announced during the period from January 1984 to December 1998 and were reported in Thomson Financial's SDC Platinum data source. The distribution of this set of acquisitions by year is shown in Table 1. For a variety of data availability reasons set out below the final samples of acquisitions analysed vary between 317 and 628 . In addition to these target firms we also identify 4,124 companies who were either acquirers or non-acquired companies in the SDC platinum database in the period 1984-1998 yielding a final maximum combined sample of 4,752 firms.

The innovation activity of firms in our sample is measured using data on the inputs to the innovation process ( $R \& D$ expenditure) and innovation output is measured in the form of intellectual property registered as patents. Apart from the raw patent count, we also consider patents in a citation weighted form to proxy for patent value (Griliches, 1990), given the evidence that the distribution of the value of patented innovations is skewed (Scherer, 1997). The number of forward citations received by a patent can be affected by its technological field, by the cohort it belongs to and may also be subject to some truncation bias. ${ }^{2}$ We therefore employ the number of 'normalised' citations using the 'fixed effects' method, which is described in Hall et al. (2001) (see Section 3.3 for details) In this way, we are able to compare patents across different technology fields and across time.

${ }^{1}$ Hall and Vopel's (1996) classification of industries is based on the industry-level R\&D-intensity and on an informal assessment of investment horizons. According to these criteria, the high technology sector consists of SIC 28, 35, 36, 37, 38, 48, 73 and 87. The eight two-digit SIC codes are as defined by Hall and Vopel (1996) with the addition of SIC 73 Business Services and 87 Engineering, Accounting, Research, Management and Related Services. SIC 73 is added to the set of high-tech SICs because many of the firms active in 357 Computer And Office Equipment are often classified as software companies with primary activity in SIC 737 Computer Programming\& Data Processing. SIC 87 is added to the set of high-tech SICs, as a large number of the companies selected based on Hall and Vopel classification had their primary activity in SIC 873 Research, Development And Testing Services.

${ }_{2}$ The truncation bias reflects the fact that patents applied for closer to the right-end of our dataset will have a smaller 'opportunity' to be cited in subsequent patents. 
Table 1. The year distribution of acquisition activity involving US public high technology firms

\begin{tabular}{|c|c|c|c|c|c|c|}
\hline \multirow[b]{3}{*}{ Year } & \multicolumn{3}{|c|}{ SDC Platinum } & \multicolumn{3}{|c|}{ Maximum sample in analysis } \\
\hline & \multirow{2}{*}{$\begin{array}{c}\begin{array}{c}\text { All } \\
\text { acquisitions }\end{array} \\
\text { No }\end{array}$} & \multicolumn{2}{|c|}{$\begin{array}{l}\text { Acquisitions with } \\
\text { value disclosed }\end{array}$} & \multirow{2}{*}{$\begin{array}{c}\begin{array}{c}\text { All } \\
\text { acquisitions }\end{array} \\
\text { No }\end{array}$} & \multicolumn{2}{|c|}{$\begin{array}{l}\text { Acquisitions with } \\
\text { value disclosed }\end{array}$} \\
\hline & & No & $\begin{array}{c}\text { Value } \\
\text { (US\$bn1996) }\end{array}$ & & No & $\begin{array}{c}\text { Value } \\
\text { (US\$bn1996) }\end{array}$ \\
\hline 1984 & 8 & 8 & 3.929 & 4 & 4 & 3.027 \\
\hline 1985 & 32 & 29 & 6.454 & 21 & 20 & 5.603 \\
\hline 1986 & 41 & 36 & 17.495 & 32 & 29 & 14.065 \\
\hline 1987 & 47 & 44 & 8.906 & 36 & 34 & 4.653 \\
\hline 1988 & 59 & 53 & 10.540 & 46 & 44 & 5.465 \\
\hline 1989 & 45 & 40 & 29.986 & 32 & 31 & 23.876 \\
\hline 1990 & 42 & 38 & 10.228 & 30 & 30 & 9.890 \\
\hline 1991 & 33 & 28 & 16.410 & 25 & 23 & 10.672 \\
\hline 1992 & 30 & 28 & 5.876 & 21 & 21 & 5.680 \\
\hline 1993 & 25 & 23 & 6.268 & 15 & 14 & 5.574 \\
\hline 1994 & 57 & 53 & 43.635 & 43 & 42 & 38.313 \\
\hline 1995 & 80 & 77 & 44.903 & 62 & 61 & 36.536 \\
\hline 1996 & 92 & 86 & 67.548 & 63 & 61 & 45.407 \\
\hline 1997 & 95 & 92 & 97.700 & 81 & 80 & 96.283 \\
\hline 1998 & 143 & 137 & 146.607 & 117 & 114 & 135.651 \\
\hline Total & 829 & 772 & 516.486 & 628 & 608 & 440.695 \\
\hline
\end{tabular}

Notes: The source of the data is SDC Platinum. Both the acquirer and the acquired firms are publicly traded firms and operate in SIC 28, 35, 36, 37, 38, 48, 73 and 87. All acquired firms are incorporated in the USA.

Financial data and data on $\mathrm{R} \& \mathrm{D}$ expenditure were collected from Datastream and Compustat. Data on patent counts and patent citations were collected from the NBER dataset, which includes all the utility patents granted by the US Patent and Trade Office (USPTO) (Hall et al., 2001). Moreover, because firms often register patents under their subsidiaries' names, we used Dun \& Bradstreet's 'Who owns whom' annual issues to obtain their detailed corporate structure and patent data were aggregated at the parent firm level.

Combining these databases we construct a unique unbalanced panel dataset covering the period 1984-1998, which, as discussed earlier, consists of financial and innovationrelated variables on a maximum of 4,752 US public firms, of which 628 have been acquired. The number of targets in the final estimation sample is less than the full sample primarily because of financial data availability. ${ }^{1}$ The sample is restricted further for data availability reasons to 317 acquisitions when we analyse the patent- and citation-weighted patent-based characteristics of firms since only a subset of the full sample is linked to patent assignees at the USPTO. The fall in the size of the sample of targets over which the preacquisition firm characteristics are assessed introduces some bias towards larger firms. The overall median size of all acquired firms equals US\$61.2 million (total assets in 1996

\footnotetext{
1 These requirements include observations on the following variables: total assets, total asset growth, operating return, Tobin's q, leverage and liquidity. They are discussed in detail later on.
} 


\section{8 of 23 P. Desyllas and A. Hughes}

constant prices), ${ }^{1}$ which is almost the same as the median size (US $\$ 61.8$ million) of the 628 targets with the required financial data. The bias is more apparent for the sample of firms over which patent-based characteristics are assessed, where the median size of the 317 targets equals US $\$ 76.3$ million.

\subsection{The model}

The probability of being acquired is modelled on the basis of individual firm characteristics. We employ a logit model to estimate the acquisition probability, since the acquisition incidence in a given year takes strictly non-negative values and hence the classical linear model is inadequate leading to heteroscedastic residuals and predicted probabilities often exceeding unity. The dependent variable is a binary variable which equals one in the year in which a given firm is acquired and zero otherwise. Similar estimation methods have been used in previous empirical work (Hall, 1988, 1999; Palepu, 1986; Powell, 1997). ${ }^{2}$

\subsection{Innovation performance variables}

The innovation performance of firms is assessed using proxies for a firm's commitment to $\mathrm{R} \& \mathrm{D}$, the $\mathrm{R} \& \mathrm{D}$ productivity of its assets, and the stock of the accumulated output of a firm's R\&D. Summary statistics of our data are presented in Table 2.

A firm's commitment to $\mathrm{R} \& \mathrm{D}$ is proxied by its $R \mathcal{E} D$-intensity (see, for example, Blonigen and Taylor, 2000; Hall, 1999; Hitt et al., 1991). The variable RED-intensity is calculated by the ratio of R\&D expenditure to total assets. ${ }^{3}$ According to the US Financial Accounting Standards Board, the accounting requirement for $\mathrm{R} \& \mathrm{D}$ expenditure disclosure is that firms should report their R\&D expenditure if it is material (i.e. exceeding $1 \%$ of sales). We follow Hall (1999), in assuming that $\mathrm{R} \& \mathrm{D}$ expenditure is immaterial whenever it is not reported but where data on most of the financial variables are available. A dummy variable (Dummy no $R \mathcal{E} D$ ) is employed for missing $R \& D$ values, which equals one when $\mathrm{R} \& \mathrm{D}$ is missing and $\mathrm{R} \& \mathrm{D}$-intensity is set equal to zero. We found that the regression results are qualitatively identical with and without this normalisation.

The R\&D productivity of a firm's assets is proxied by its Patent-intensity. The variable Patent-intensity is calculated by the ratio of the number of successful patent applications to US $\$$ million (1996 constant prices) of total assets. Apart from the continuous variable, a dummy variable (Dummy zero patent-intensity) is employed for firms with zero patentintensity, to distinguish between firms with some versus no innovation output. The patentintensity is also calculated using the number of citations received by forward patents to

\footnotetext{
${ }^{1}$ All financial variables are expressed in constant 1996 prices using the US gross domestic product deflator, which effectively averages how consumers, producers and the public sector experience inflation.

2 A small number of studies of takeover incidence have used hazard rate analysis with right hand side censoring to predict whether a firm is acquired given that it has not been acquired before time $t$. This approach has some advantages (see, e.g., Dickerson et al., 2002), but requires consistent data on business age, which is not always available in our dataset and may be a noisy variable given that age is difficult to measure, except in terms of date of first public creation in the current company form. Moreover, it has been shown in the medical literature on mortality that under reasonable conditions the hazard rate and logistic approaches are asymptotically similar, and in many applications reveal essentially similar results (see, e.g., D'Agostino et al., 1990). Dickerson et al. (2002) also report similar sets of determinants of the acquisiton likelihood using logit and hazard rate approaches in terms of statistical significance and sign although the estimated coefficients vary in size between models.

${ }^{3}$ Some studies calculate R\&D-intensity as the ratio of R\&D-expenditure to sales. Because we proxy firm size by total assets, we use the same variable in the denominator of the ratio for consistency reasons.
} 
Table 2. Summary statistics for sample firms

\begin{tabular}{|c|c|c|c|c|c|c|c|c|c|}
\hline \multirow[b]{2}{*}{ Variable } & \multicolumn{3}{|c|}{$\begin{array}{c}\text { All firms } \\
(\max \text { no }=4,752)\end{array}$} & \multicolumn{3}{|c|}{$\begin{array}{l}\text { Acquired firms } \\
(\max \text { no }=628)\end{array}$} & \multicolumn{3}{|c|}{$\begin{array}{l}\text { Non-acquired firms } \\
(\max \text { no }=4,124)\end{array}$} \\
\hline & Mean & Median & SD & Mean & Median & SD & Mean & Median & SD \\
\hline \multicolumn{10}{|l|}{ R\&D-intensity } \\
\hline$R \& D-i$ & 0 & & & & & & & & 0 \\
\hline Patent-intensi & 0 & 2 & & & & 0 & 44 & & 0.13 \\
\hline Patent-intensity, & & & & & & & & & \\
\hline & 0.055 & 0.000 & 0.212 & 0.053 & 0.000 & 0.204 & 0.055 & 0.000 & 0.2 \\
\hline $\ln$ (patent stock) & -0.109 & 1.331 & 4.887 & 0.661 & 1.534 & 3.821 & -0.125 & 1.318 & 4.90 \\
\hline $\begin{array}{l}\text { In (patent stock, } \\
\text { citation-weighte }\end{array}$ & -0.298 & & & & & & & & \\
\hline $\ln ($ tot & 10.799 & 10.638 & 2.288 & 11.195 & 11.032 & 1.741 & 10.791 & 10.629 & 2.297 \\
\hline Total a & 0.418 & 0.055 & 1.581 & 0.304 & 0.062 & 1.200 & 0.420 & 0.055 & 1.588 \\
\hline Operating return & -0.042 & 0.101 & 0.520 & 0.004 & 0.106 & 0.366 & -0.043 & 0.101 & 0.523 \\
\hline $\ln$ (Tobin's q) & 0.647 & 0.494 & 0.718 & 0.534 & 0.407 & 0.718 & 0.648 & 0.495 & 0.718 \\
\hline Lev & 0.476 & 151 & 2.646 & 0.442 & 0.162 & 2.288 & 0.477 & 0.151 & 2.653 \\
\hline Liquidity & 3.607 & 2.296 & 4.561 & 3.279 & 2.491 & 3.009 & 3.613 & 2.292 & 4.586 \\
\hline
\end{tabular}

Notes: R\&D-intensity is reported both unadjusted and adjusted where missing observations are assumed to be zero if data on all the financial variables considered are available. SD, standard deviation.

account not only for the quantity (raw patent count) but also the quality of the patented inventions. In order to account for possible biases arising from differences across patent technological field and cohorts we employ the number of 'normalised' citations by dividing the number of citations that a given patent received with the average number of citations received by all patents that were applied for in the same year within the same technological classification (Hall et al., 2001).

The accumulated output of a firm's R\&D is proxied by its Patent Stock. The variable Patent Stock is calculated from the flow of successful patent applications using the standard perpetual inventory formula (see Hall, 1990). The patent stock at time $t$ equals the last period's patent stock, after depreciation at rate $\delta$ (assumed 15\%) is deducted, plus the number of patents at time $t$.

This variable, contrary to the other innovation proxies providing information for the last pre-acquisition year, has 6-7 years memory. In order to reduce the large variance of patent stock across firms and fulfil the assumptions necessary for the validity of regression inferences, it is transformed in natural logarithm (ln) terms. We proxy for the accumulated innovation stock using the stock of patents rather than of $R \& D$ expenditure, because the patent series do not suffer from the widespread time discontinuities present in the R\&D expenditure series. The patent stock is also calculated using the number of normalised citations received by forward patents.

\subsection{Economic performance variables and other control variables}

In accordance with earlier studies on modelling the acquisition likelihood (Hall, 1988, 1999; Palepu, 1986; Powell, 1997), the set of firm characteristics that were considered to 


\section{0 of 23 P. Desyllas and A. Hughes}

model the acquisition probability include control variables accounting for a firm's economic performance, its size and financial resources.

The likelihood of being acquired has been found to be negatively related to economic performance (Agrawal and Jaffe, 2003; Dickerson et al., 2002; Hasbrouck, 1985; McConnell and Martin, 1991; Morck et al., 1988; Palepu, 1986; Powell, 1997). ${ }^{1}$ The economic performance is assessed along three dimensions. Total Asset Growth is employed as a proxy for firm growth. It is calculated by the annual growth of total assets measured in real terms. Operating Return is employed as a proxy for a firm's profitability. It is calculated by the ratio of earnings before interest taxation, depreciation and amortisation (EBITDA) to total assets. Similar to Hall (1999), apart from the continuous variable, a dummy variable (Dummy Op. Return Negative) is employed for very negative operating returns, that is for EBITDA losses of more than half the firm's total assets, in which case the continuous variable is set to zero. Tobin's $q$, having a forward looking numerator, is employed as a proxy for a firm's growth opportunities (Gugler et al., 2004; Powell, 1997). However, the interpretation of its effect on the acquisition likelihood should be treated with care, since it is also likely to reflect stock misvaluations (Morck et al., 1988; Rhodes-Kopf et al., 2005; Shleifer and Vishny, 2001). Therefore, its interpretation should be made in the light of the results about targets' economic and innovation performance. Tobin's q is calculated by the natural logarithm of the ratio of total assets plus the market value of common equity minus the book value of common equity to total assets (see Andrade and Stafford, 2004; Blanchard et al., 1994; Kaplan and Zingales, 1997). ${ }^{2}$

It has been argued that the acquisition probability is negatively related with firm size because of the 'transaction costs' of target absorption (Palepu, 1986; Powell, 1997). The variable Total Assets is employed as a proxy for firm size. It is measured in US\$thousands (1996 constant prices) and it is expressed in terms of the natural logarithm. We have chosen this specific size measure because it has the best coverage among all the alternatives considered (sales, number of employees). A similar size proxy has been used in other studies (e.g. Powell, 1997). In addition, after some preliminary analysis, which suggested that targets tend to be larger than 'normal', a squared term of the size proxy was introduced as we suspect the existence of a non-linear relationship between size and the acquisition likelihood (Dickerson et al., 2002, 2003; Hughes, 1993). ${ }^{3}$

The availability of financial resources has been identified as a crucial determinant of the probability of being acquired (Palepu, 1986). It has been argued that acquirers may prefer to acquire firms with high liquidity and low leverage to reduce the leverage of the combined company (Eddey, 1991). Leverage is employed as a proxy for a firm's sources of finance and its financial risk. It is calculated as the ratio of long-term debt to the book value of common equity. Liquidity is employed as a proxy for a firm's ability to meet its short-term obligations from its current assets. It is calculated as the ratio of current assets to current liabilities.

\footnotetext{
1 This is particularly true for targets in hostile acquisitions. In our sample, such a distinction is not possible since hostile acquisitions account for only $2.3 \%$ of all deals.

2 This approximation has the advantage over the alternative measures that we considered (e.g. Blundell et al., 1992; Hall, 2000) in that it is easy to calculate and it has better sample coverage than the alternatives. However, it does have shortcomings (Andrade and Stafford, 2004): it assumes that the replacement cost of assets and liabilities is well proxied by their book value, it assumes that the average and the marginal $\mathrm{q}$ are the same and it ignores tax effects. The conceptually correct measure comparing replacement costs to market values requires data that is frequently missing in financial datasets, and considerable imputation, which made it impractical in this study. For a recent discussion of alternative 'q' estimators see Lee (1999).

3 There is evidence that, as financial constraints have become relatively looser, increasingly larger firms can be taken over (Hughes, 1993).
} 
All covariates have been lagged by one year to avoid endogeneity problems. Because we find evidence for the existence of some influential outliers, data are winsorised at $1 \%(0.5 \%$ from each side). Finally, industry and time dummy variables are added to the set of the control variables. They are employed to control for industry-specific factors, such as technological change and restructuring, as well as for stock market fluctuations (Gort, 1969; Mitchell and Muhlerin, 1996; Shleifer and Vishny, 2001). In this way, we account for the possibility of time or cross-sectional dependence of deals (Beck et al., 1997). ${ }^{1}$

\section{Results}

\subsection{The innovation characteristics of firms and the acquisition likelihood}

Given the cross-section and time series nature of our dataset we initially considered panel data estimation methods, which have the advantage that they allow us to account for some unobserved heterogeneity across firms. However, we found that the proportion of total variance contributed by the panel variance component equals $2.53 \mathrm{e}-07$ and the hypothesis that the panel-level variance component equals zero could not be rejected at the $5 \%$ significance level. ${ }^{2}$ As a result the estimates from the panel estimator were identical to those from the pooled estimator and, hence, only the pooled logit model estimates are reported. Robust standard errors to within-firm serial correlation are calculated, since even if firmspecific effects are uncorrelated with the regressors, the composite errors might be serially correlated due to the presence of a firm-specific effect in each time period.

In order to check for possible biases that may arise from missing observations for some of the regressors and the endogeneity of patents on $\mathrm{R} \& \mathrm{D}$, we estimate five regression specifications of the logit model (see Table 3). The first three regressions assess the effect of each of the three innovation characteristics (R\&D-intensity, patent-intensity, patent stock) on the likelihood of becoming acquired, while controlling for some key firm characteristics (total assets, total asset growth and operating return). The first regression examines the effect of R\&D-intensity, while the other two regressions examine the effect of patentintensity and patent stock, in raw and citation-weighted form. Specification (4) includes R\&D-intensity, patent-intensity and patent stock in citation-weighted form contemporaneously, while controlling for key firm characteristics. Specification (5) includes the same innovation variables and controls for the full set of firm characteristics (total assets, total asset growth, operating return, Tobin's q, leverage and liquidity). The largest sample is utilised in specification (1) where there are 32,342 observations on 4,752 firms of which 628 are acquired, and it falls to 10,702 observations on 1,288 firms of which 166 are acquired in specification (5). For all five regressions the Chi-squared test rejects the null hypothesis that the model as a whole does no better than simply using a constant term $(P<0.01$ in all cases). The modest value of the likelihood ratio index, ranging from $4 \%$ to $7 \%$, is not surprising, given that comparable or even lower levels are reported in previous relevant studies (Hall, 1999; Palepu, 1986; Powell, 1997). The firm characteristics that are

\footnotetext{
${ }^{1}$ Industry groups are defined at the two-digit SIC level, with the exception of firms in SIC 283, which are distinguished from those in SIC 28 (excluding 283), since they are likely to have distinct characteristics, such as a significantly higher $\mathrm{R} \& \mathrm{D}$-intensity.

2 The result that unobservable firm characteristics are not important in explaining the likelihood of becoming acquired could be taken as evidence that the acquisition activity of high technology acquirers is not directed towards firms with non-quantifiable resources and capabilities. This fact increases the likelihood that, to the extent that targets have particular characteristics, these characteristics should be reflected in our independent and control variables.
} 
Table 3. Parameter estimates of the logit models: the dependent variable is a binary indicator of being acquired

\begin{tabular}{|c|c|c|c|c|c|c|c|c|c|c|}
\hline \multirow[b]{3}{*}{ Regressor } & \multicolumn{2}{|c|}{ (1) } & \multicolumn{2}{|c|}{ (2) } & \multicolumn{2}{|c|}{ (3) } & \multicolumn{2}{|c|}{$(4)$} & \multicolumn{2}{|c|}{ (5) } \\
\hline & \multicolumn{2}{|c|}{$\begin{array}{c}\mathrm{R} \& \mathrm{D} \text { and } \\
\text { controls }\end{array}$} & \multicolumn{2}{|c|}{$\begin{array}{l}\text { Patents and } \\
\text { controls }\end{array}$} & \multicolumn{2}{|c|}{$\begin{array}{l}\text { Citation- } \\
\text { weighted patents } \\
\text { and controls }\end{array}$} & \multicolumn{2}{|c|}{$\begin{array}{l}\text { R\&D, citation- } \\
\text { weighted patents } \\
\text { and controls }\end{array}$} & \multicolumn{2}{|c|}{$\begin{array}{l}\text { R\&D, citation- } \\
\text { weighted patents } \\
\text { and all controls }\end{array}$} \\
\hline & Coef. & SE & Coef. & SE & Coef. & SE & Coef. & SE & Coef. & SE \\
\hline R\&D-intensity & $1.772^{\star \star \star}$ & $(0.329)$ & & & & & $1.336^{\star \star \star}$ & $(0.506)$ & $0.914^{\star}$ & $(0.512)$ \\
\hline Dummy no. R\&D & 0.048 & $(0.162)$ & & & & & -0.139 & $(0.320)$ & -0.310 & $(0.305)$ \\
\hline Patent-intensity & & & -0.031 & $(0.947)$ & 0.388 & $(0.473)$ & 0.308 & $(0.480)$ & 0.503 & $(0.406)$ \\
\hline Dummy zero patent-intensity & & & $0.454^{\star}$ & $(0.251)$ & $0.615^{\star \star}$ & $(0.253)$ & $0.639^{\star \star}$ & $(0.253)$ & $0.576^{\star \star}$ & $(0.242)$ \\
\hline $\ln$ (Patent stock) & & & $0.071^{\star \star \star}$ & $(0.027)$ & $0.066^{\star \star \star}$ & $(0.025)$ & $0.061^{\star \star}$ & $(0.025)$ & $0.039^{\star}$ & $(0.024)$ \\
\hline $\ln$ (Total assets) & $2.692^{\star \star \star}$ & $(0.301)$ & $2.984^{\star \star \star}$ & $(0.446)$ & $2.973^{\star \star \star}$ & $(0.447)$ & $3.019^{\star \star \star}$ & $(0.442)$ & $2.251^{\star \star \star}$ & $(0.437)$ \\
\hline $\ln$ (Total assets) $^{2}$ & $-0.109^{\star \star \star}$ & $(0.013)$ & $-0.122^{\star \star \star}$ & $(0.019)$ & $-0.120^{\star \star \star}$ & $(0.019)$ & $-0.121^{\star \star \star}$ & $(0.019)$ & $-0.089^{\star \star \star}$ & $(0.018)$ \\
\hline Total assets growth & $-0.163^{\star \star}$ & $(0.066)$ & -0.105 & $(0.113)$ & -0.105 & $(0.115)$ & -0.098 & $(0.114)$ & -0.021 & $(0.130)$ \\
\hline Operating return & -0.517 & $(0.360)$ & -0.653 & $(0.646)$ & -0.613 & $(0.641)$ & -0.418 & $(0.627)$ & 0.006 & $(0.621)$ \\
\hline Dummy op. return negative & -0.398 & $(0.332)$ & $0.796^{\star \star}$ & $(0.388)$ & $0.769^{\star \star}$ & $(0.391)$ & 0.298 & $(0.443)$ & 0.405 & $(0.443)$ \\
\hline $\ln ($ Tobin's q) & & & & & & & & & -0.227 & $(0.167)$ \\
\hline Leverage & & & & & & & & & -0.005 & $(0.034)$ \\
\hline Liquidity & & & & & & & & & $-0.059^{\star \star}$ & $(0.026)$ \\
\hline Constant & $-21.190^{\star \star \star}$ & $(1.789)$ & $-23.293^{\star \star \star}$ & $(2.786)$ & $-23.618^{\star \star \star}$ & $(2.788)$ & $-24.279^{\star \star \star}$ & $(2.790)$ & $-18.785^{\star \star \star}$ & $(2.841)$ \\
\hline Year dummies (LR test) & $97.6^{\star \star \star}$ & & $43.1^{\star \star \star}$ & & $40.0^{\star \star \star}$ & & $38.7^{\star \star \star}$ & & $55.1^{\star \star \star}$ & \\
\hline Industry dummies (LR test) & $33.9^{\star \star \star}$ & & $14.7^{\star}$ & & $14.5^{\star}$ & & $14.2^{\star}$ & & $24.1^{\star \star \star}$ & \\
\hline No. observations & 32,342 & & 15,762 & & 15,762 & & 15,762 & & 10,702 & \\
\hline No. firms & 4,752 & & 1,958 & & 1,958 & & 1,958 & & 1,288 & \\
\hline No. targets & 628 & & 317 & & 317 & & 317 & & 166 & \\
\hline$X^{2}$ test & $411.6^{\star \star \star}$ & & $166.4^{\star \star \star}$ & & $168.3^{\star \star \star}$ & & $177.0^{\star \star \star}$ & & $154.2^{\star \star \star}$ & \\
\hline Likelihood ratio index & 0.05 & & 0.04 & & 0.04 & & 0.04 & & 0.07 & \\
\hline Log likelihood & $-2,943.7$ & -1 & ,487.2 & &, 486.2 & & $1,483.9$ & & -797.1 & \\
\hline
\end{tabular}
${ }^{\star \star \star} P<0.01 ;{ }^{\star \star} P<0.05 ;{ }^{\star} P<0.1$.
Notes: The estimated coefficients (Coef.) and corresponding standard errors (SE) are reported in terms of marginal effects evaluated at the averages of the regressors
and the coefficients are multiplied by 100 . Robust standard errors to within-firm serial correlation are reported in parentheses. In all regressions the base industry is SIC 283 and the base year is 1998 . 
employed as regressors are found to be jointly significant by a likelihood ratio test in all three regressions. However, a part of the explanatory power of the model seems to come from the year and industry dummies, which are also jointly significant.

The results shown in Table 3 are reported in terms of marginal effects evaluated at the averages of the regressors and the coefficients are multiplied by 100 for clarity of exposition. We consistently find that the acquired firms have a significantly higher R\&Dintensity compared with non-acquired firms. This finding is robust to the different specifications that are employed. Although no linear relationship between patent-intensity and the acquisition likelihood emerges, we obtain a significantly positive coefficient of the dummy for zero patent-intensity in both raw and citation-weighted form. This suggests that firms that are acquired are more likely to have a zero patent-intensity and this dummy is equal to unity for more than half of the acquired firms. Despite the finding for a zero patent-intensity in the year before the acquisition, there is evidence that the firms acquired tend to have a significantly larger patent stock compared with non-acquired firms. As can be seen from Table 3, these relationships are not sensitive to the inclusion of R\&D-intensity and the control variables.

In relation to the control variables, the likelihood of a firm being acquired is positively related to firm size, but only up to a certain level, after which it decreases as the significantly negative squared term for firm size suggests. The likelihood of being acquired reaches its maximum for firms with total assets of about $\ln 12.7$, while the mean for all firms in the regression is $\ln 11.5$ [data from specification (5)]. There is some indication that the acquisition likelihood is higher for firms with very negative operating returns and with significantly low liquidity.

In order to assess the size of the contribution of each of the three innovative firm characteristics to the acquisition probability, we examine how the probability changes given a marginal movement in each of these variables that is equal to their standard deviation. We focus on the statistically significant coefficients from specification (5). A marginal increase in the $\mathrm{R} \& \mathrm{D}$-intensity raises the probability of making acquisitions by $0.0014[\approx$ marginal effect of $\mathrm{R} \& \mathrm{D}$-intensity evaluated at sample means of regressors $(0.0091) \times$ standard deviation of R\&D-intensity (0.1573)], or by $9.3 \%$ had the probability previously been at its sample mean value. In relation to the citation-weighted patentintensity, the derivative figure for the dummy for zero citation-weighted patent-intensity indicates that having a zero citation-weighted patent-intensity versus having a positive intensity increases the acquisition probability by 0.0024 , holding other factors constant. Thus, a marginal move in the dummy increases the acquisition probability by 0.0029 , or by $18.6 \%$, had the probability previously been at its sample mean. Finally, a marginal increase in the citation-weighted patent stock increases the acquisition probability by 0.0020 , or $12.8 \%$.

Taken together, these results suggest that targets tend to have a high R\&D-intensity, a large accumulated patent stock, but zero patent-intensity in the year before acquisition. Interestingly, the results suggest that the innovation characteristics of firms contribute to the explanation of the acquisition likelihood over and above the financial characteristics of firms, at least in a high technology environment.

\subsection{Sensitivity checks}

There is evidence in the acquisition literature that the determinants of the probability of being acquired change over time (Dickerson et al., 2003; Powell, 1997). In particular, 


\section{4 of 23 P. Desyllas and A. Hughes}

because of the equity price rally since the mid-1990s, one might suspect that a large part of the acquisition activity has been driven by stock market misvaluations (Gugler et al., 2004; Rhodes-Kropf et al., 2005; Shleifer and Vishny, 2001). We check the robustness of our results by splitting our sample period into two subperiods: from 1984 to 1994 and from 1995 until 1998. During the 11-year period 1984-1994 the S\&P 500 return index rose by 300 points to 465 points and 419 public high technology firms were acquired; during the four-year period 1995-1998 the S\&P 500 index rose by 505 points to 970 points and 410 public firms were acquired (Datastream and SDC data). ${ }^{1}$ Table 4 reports results for our regressions including $\mathrm{R} \& \mathrm{D}$-intensity, patent-intensity and patent stock in citation-weighted form and control variables.

The coefficient of R\&D-intensity is significantly positive in both subperiods in specification (1), and in the first subperiod in specification (2). In the first subperiod, we find evidence for the existence of a negative relationship between citation-weighted patent-intensity and the acquisition likelihood in both specifications. This relationship becomes weaker in the second subperiod, when the sign of the continuous variable becomes positive and insignificant, but we now obtain a significantly positive coefficient for the dummy for zero citation-weighted patent-intensity. The coefficient of the citation-weighted patent stock is consistently positive but it is statistically significant only in the second subperiod in specification (1). In relation to the financial variables, it is interesting to notice that the evidence for a poor pre-acquisition operating return holds only in the first subperiod. We obtain a significantly negative relationship between operating return and the acquisition likelihood in the first subperiod, which is also statistically significant in specification (1). However, this relationship is reversed in the second subperiod, where the operating return coefficient also becomes statistically significant in specification (2). Apart from some indication for low financial liquidity in the first subperiod, no other significant relationship emerges. We conclude that the finding that the firms acquired are characterised by innovation and economic underperformance holds more strongly in the first subperiod. One possibility is that the explanatory power of neoclassical views of acquisitions, such as the market for corporate control hypothesis (a variation of which is tested), weakens during periods of stock market valuation waves (Hughes, 1993; Rhodes-Kropf et al., 2005; Shleifer and Vishny, 2001).

Finally, we check whether our results are sensitive to the size normalisation that we have employed. Given that assets are an accounting-based measure, the variable total assets is subject to potential problems. We re-estimate the logit regressions when $\mathrm{R} \& \mathrm{D}$-intensity and patent-intensity are normalised by sales and firm size and growth are calculated using sales and sales growth. As can be seen from Table 5, the innovation-related results from both specifications are qualitatively identical to those from the corresponding specifications of Table 2. In relation to the controls, there is evidence that targets are somewhat larger and they tend to experience lower performance than average.

\subsection{Further analysis: acquired versus acquiring firms}

Having studied the innovative characteristics of targets relative to non-acquired firms, we examine for each couple (i.e. acquirer and target) in a particular acquisition their relative

1 To test for a structural break we chose the year 1995 by inspection of the daily returns of the S\&P500 index. The likelihood ratio test for a structural break in 1995 confirms the structural break hypothesis (LR Test $=1481.3, P<0.01)$. Estimation of a single regression over the full period from 1984 to 1998 could thus lead to biased parameter estimates. 
Table 4. Parameter estimates of the logit models by time period: the dependent variable is a binary indicator of being acquired

\begin{tabular}{|c|c|c|c|c|c|c|c|c|}
\hline \multirow[b]{3}{*}{ Regressor } & \multicolumn{4}{|c|}{$\begin{array}{l}\text { (1) } \mathrm{R} \& \mathrm{D} \text {, Citation-weighted } \\
\text { patents and controls }\end{array}$} & \multicolumn{4}{|c|}{$\begin{array}{l}\text { (2) } \mathrm{R} \& \mathrm{D} \text {, Citation-weighted } \\
\text { patents and all controls }\end{array}$} \\
\hline & \multicolumn{2}{|c|}{ 1984-1994 } & \multicolumn{2}{|c|}{ 1995-1998 } & \multicolumn{2}{|c|}{ 1984-1994 } & \multicolumn{2}{|c|}{ 1995-1998 } \\
\hline & Coef. & SE & Coef. & SE & Coef. & SE & Coef. & SE \\
\hline R\&D-intensity & $1.284^{\star \star}$ & $(0.631)$ & $2.159^{\star \star}$ & $(0.934)$ & $1.400^{\star}$ & $(0.731)$ & 0.773 & $(0.678)$ \\
\hline Dummy no R\&D & -0.092 & $(0.311)$ & -0.047 & $(0.740)$ & -0.266 & $(0.350)$ & -0.131 & $(0.428)$ \\
\hline Patent-intensity & $-0.697^{\star}$ & $(0.422)$ & 1.270 & $(0.784)$ & $-0.298^{\star}$ & $(0.181)$ & 0.852 & $(0.523)$ \\
\hline Dummy zero patent-intensity & 0.240 & $(0.274)$ & $1.492^{\star \star \star}$ & $(0.542)$ & 0.435 & $(0.304)$ & $0.668^{\star}$ & $(0.348)$ \\
\hline $\begin{array}{l}\ln \text { (Patent stock) } \\
\text { (P) }\end{array}$ & 0.036 & $(0.025)$ & $0.119^{\star \star}$ & $(0.059)$ & 0.032 & $(0.029)$ & 0.037 & $(0.036)$ \\
\hline $\ln$ (Total assets) & $2.616^{\star \star \star}$ & $(0.472)$ & $3.689^{\star \star \star}$ & $(0.973)$ & $2.372^{\star \star \star}$ & $(0.563)$ & $1.642^{\star \star}$ & $(0.650)$ \\
\hline $\ln$ (Total assets) $^{2}$ & $-0.107^{\star \star \star}$ & $(0.020)$ & $-0.145^{\star \star \star}$ & $(0.041)$ & $-0.094^{\star \star \star}$ & $(0.023)$ & $-0.065^{\star \star}$ & $(0.027)$ \\
\hline Total assets growth & -0.358 & $(0.219)$ & 0.036 & $(0.138)$ & -0.351 & $(0.359)$ & 0.107 & $(0.097)$ \\
\hline Operating return & $-1.203^{\star}$ & $(0.655)$ & 1.591 & $(1.356)$ & -0.834 & $(0.762)$ & $1.763^{\star}$ & $(0.956)$ \\
\hline Dummy op. return negative & -0.519 & $(0.739)$ & 1.104 & $(0.756)$ & -0.671 & $(0.950)$ & 0.794 & $(0.510)$ \\
\hline $\ln$ (Tobin's q) & & & & & -0.220 & $(0.203)$ & -0.172 & $(0.267)$ \\
\hline Leverage & & & & & -0.033 & $(0.034)$ & 0.045 & $(0.053)$ \\
\hline Liquidity & & & & & $-0.058^{\star \star}$ & $(0.027)$ & -0.058 & $(0.048)$ \\
\hline Constant & $-19.531^{\star \star \star}$ & $(2.947)$ & $-33.233^{\star \star \star}$ & $(6.102)$ & $-17.543^{\star \star \star}$ & $(3.672)$ & $-15.473^{\star \star \star}$ & $(3.930)$ \\
\hline Year dummies (LR test) & $29.8^{\star \star \star}$ & & 0.7 & & $24.5^{\star \star \star}$ & & $26.9^{\star \star \star}$ & \\
\hline Industry dummies (LR test) & $16.2^{\star \star}$ & & $19.5^{\star \star}$ & & $47.1^{\star \star \star}$ & & $48.0^{\star \star \star}$ & \\
\hline No. observations & 10,431 & & 5,101 & & 6,849 & & 3,557 & \\
\hline No. firms & 1,504 & & 1,524 & & 960 & & 1,076 & \\
\hline No. targets & 175 & & 142 & & 107 & & 59 & \\
\hline$X^{2}$ test & $144.7^{\star \star \star}$ & & $61.4^{\star \star \star}$ & & $111.5^{\star \star \star}$ & & $58.0^{\star \star \star}$ & \\
\hline Likelihood ratio index & 0.06 & & 0.04 & & 0.08 & & 0.10 & \\
\hline Log likelihood & -839.4 & & -622.9 & & -508.9 & & -269.0 & \\
\hline
\end{tabular}

$\star \star \star P<0.01 ;{ }^{\star \star} P<0.05 ;{ }^{\star} P<0.1$

Notes: Patents are measured in citation-weighted form. The estimated coefficients (Coef.) and corresponding standard errors (SE) are reported in terms of marginal effects evaluated at the averages of the regressors and the coefficients are multiplied by 100 . Robust standard errors to within-firm serial correlation are reported in parentheses. In all regressions the base industry is SIC 283 and the base year is the final year included in each subperiod. 


\section{6 of 23 P. Desyllas and A. Hughes}

Table 5. Parameter estimates of the logit models—firm size proxied by sales: the dependent variable is a binary indicator of being acquired

(1)

\begin{tabular}{|c|c|c|c|c|}
\hline \multirow[b]{2}{*}{ Regressor } & \multicolumn{2}{|c|}{$\begin{array}{l}\text { R\&D, Citation- } \\
\text { weighted patents } \\
\text { and controls }\end{array}$} & \multicolumn{2}{|c|}{$\begin{array}{l}\text { R\&D, Citation- } \\
\text { weighted patents } \\
\text { and all controls }\end{array}$} \\
\hline & Coef. & SE & Coef. & SE \\
\hline R\&D-intensity & $0.086^{\star}$ & $(0.051)$ & $0.084^{\star}$ & $(0.045)$ \\
\hline Dummy no R\&D & -0.255 & $(0.311)$ & -0.353 & $(0.296)$ \\
\hline Patent-intensity & 0.075 & $(0.191)$ & 0.062 & $(0.214)$ \\
\hline Dummy zero patent-intensity & $0.551^{\star \star}$ & $(0.240)$ & $0.487^{\star \star}$ & $(0.226)$ \\
\hline ln (Patent stock) & $0.065^{\star \star \star}$ & $(0.024)$ & $0.045^{\star}$ & $(0.023)$ \\
\hline $\ln$ (Sales) & $3.054^{\star \star \star}$ & $(0.385)$ & $2.269^{\star \star \star}$ & $(0.371)$ \\
\hline $\ln$ (Sales) $^{2}$ & $-0.123^{\star \star \star}$ & $(0.016)$ & $-0.090^{\star \star \star}$ & $(0.015)$ \\
\hline Sales growth & 0.033 & $(0.059)$ & -0.01 & $(0.090)$ \\
\hline Operating return & $-1.567^{\star \star}$ & $(0.639)$ & -0.853 & $(0.626)$ \\
\hline Dummy op. return negative & $1.027^{\star \star}$ & $(0.410)$ & $0.949^{\star \star}$ & $(0.412)$ \\
\hline $\ln ($ Tobin's q) & & & -0.141 & $(0.168)$ \\
\hline Leverage & & & -0.006 & $(0.032)$ \\
\hline Liquidity & & & -0.023 & $(0.026)$ \\
\hline Constant & $-23.581^{\star \star \star}$ & $(2.351)$ & $-18.425^{\star \star \star}$ & $(2.452)$ \\
\hline Year dummies (LR test) & $38.2^{\star \star \star}$ & & $55.1^{\star \star \star}$ & \\
\hline Industry dummies (LR test) & $16.2^{\star \star}$ & & $24.7^{\star \star \star}$ & \\
\hline No. observations & 15,315 & & 10,452 & \\
\hline No. firms & 1,909 & & 1,262 & \\
\hline No. targets & 310 & & 163 & \\
\hline$X^{2}$ test & $193.2^{\star \star \star}$ & & $159^{\star \star \star}$ & \\
\hline Likelihood ratio index & 0.05 & & 0.07 & \\
\hline Log likelihood & $-1,445.1$ & & -778.8 & \\
\hline
\end{tabular}

$\star \star \star P P<0.01 ;{ }^{\star} P P<0.05 ;{ }^{\star} P<0.1$

Notes: Firm size is proxied by Sales; R\&D-intensity and Patent-intensity are normalised by Sales. Patents are measured in citation-weighted form. The estimated coefficients (Coef.) and corresponding standard errors (SE) are reported in terms of marginal effects evaluated at the averages of the regressors and the coefficients are multiplied by 100 . Robust standard errors to within-firm serial correlation are reported in parentheses. In all regressions the base industry is SIC 283 and the base year is 1998.

characteristics using a univariate analysis. The couples of firms are compared with respect to the same proxies for innovation and economic performance that we considered above. The median differences for the variables across all the couples of acquiring-acquired firms with available data are reported in Table 6 . The differences are calculated both in an unadjusted form (target minus acquirer) and a control-adjusted form in order to control for industry, time and firm size effects (Barber and Lyon, 1996). Each acquiring (acquired) firm is matched to a control non-acquiring (non-acquired) firm from the same industry matching size similarities as closely as possible. ${ }^{1}$ Then, for each variable we calculate the difference between a target firm minus its matched control and its acquirer minus its

1 The potential controls of an acquiring firm are firms which were not active in any acquisition activity over the three pre- and post-acquisition years, and that potential controls for an acquired firm are non-acquired firms during the 3 years following the year in which the firm in question is acquired. The imposition of this acquisition abstinence window for controls is adopted since we carry out a one-to-one matching. 
Table 6. Pairwise univariate comparisons of targets and their acquirers

\begin{tabular}{|c|c|c|c|c|c|c|c|c|c|}
\hline & \multirow[b]{2}{*}{ Firm no. } & \multirow{2}{*}{$\frac{\text { Targets }}{\text { Median }}$} & \multirow{2}{*}{$\frac{\text { Acquirers }}{\text { Median }}$} & \multicolumn{2}{|c|}{$\begin{array}{l}\text { Target minus } \\
\text { acquirer }\end{array}$} & \multirow{2}{*}{$\begin{array}{c}\begin{array}{c}\text { Targets } \\
\text { control-adjusted }\end{array} \\
\text { Median }\end{array}$} & \multirow{2}{*}{$\frac{\begin{array}{c}\text { Acquirers } \\
\text { control-adjusted }\end{array}}{\text { Median }}$} & \multicolumn{2}{|c|}{$\begin{array}{c}\text { Target } \\
\text { control-adjusted } \\
\text { minus acquirer } \\
\text { control-adjusted }\end{array}$} \\
\hline & & & & Median & $\%$ Positive & & & Median & $\%$ Positive \\
\hline R\&D-intensity & 212 & 0.093 & 0.062 & $0.017^{\star \star \star}$ & $59.8^{\star \star \star}$ & 0.011 & 0.005 & 0.006 & 52.1 \\
\hline Patent-intensity & 212 & 0.006 & 0.012 & 0.000 & 46.8 & 0.000 & 0.005 & -0.003 & 46.0 \\
\hline $\begin{array}{l}\text { Patent-intensity, } \\
\text { citation-weighted }\end{array}$ & 212 & 0.000 & 0.010 & $0.000^{\star}$ & $38.0^{\star \star \star}$ & 0.000 & 0.004 & $-0.004^{\star \star}$ & $40.1^{\star \star \star}$ \\
\hline ln (Patent Stock) & 212 & 1.634 & 3.696 & $-2.293^{\star \star \star}$ & $23.6^{\star \star \star}$ & 0.000 & 1.586 & $-1.630^{\star \star \star}$ & $30.7^{\star \star \star}$ \\
\hline citation-weighted) & 212 & 2.001 & 4.125 & $-2.420^{\star \star \star}$ & $20.0^{\star \star \star}$ & 0.097 & 1.618 & $-1.934^{\star \star \star}$ & $33.5^{\star \star \star}$ \\
\hline $\ln$ (Total Assets) & 212 & 11.303 & 14.115 & $-2.379^{\star \star \star}$ & $8.5^{\star \star \star}$ & 0.028 & 0.378 & $-0.411^{\star \star \star \star}$ & 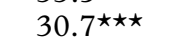 \\
\hline Total Assets Growth & 212 & 0.043 & 0.111 & $-0.081^{\star \star \star}$ & $38.2^{\star \star \star}$ & -0.044 & 0.063 & $-0.112^{\star}$ & $41.0^{\star \star \star}$ \\
\hline Operating Return & 212 & 0.103 & 0.180 & $-0.066^{\star \star \star}$ & $32.5^{\star \star \star}$ & -0.029 & 0.050 & $-0.066^{\star \star \star}$ & $34.9^{\star \star \star}$ \\
\hline $\ln$ (Tobin's q) & 61 & 0.472 & 0.566 & $-0.295^{\star \star}$ & $36.1^{\star \star}$ & -0.220 & 0.122 & $-0.305^{\star \star}$ & $36.1^{\star \star}$ \\
\hline Leverage & 206 & 0.135 & 0.240 & -0.031 & 45.1 & 0.000 & 0.003 & 0.026 & 51.9 \\
\hline Liquidity & 196 & 2.701 & 2.382 & $0.322^{\star \star}$ & $58.2^{\star \star}$ & -0.140 & 0.121 & $-0.321^{\star}$ & 44.9 \\
\hline
\end{tabular}

$\star \star \star \star P<0.01 ;{ }^{\star \star} P<0.05 ;{ }^{\star} P<0.1$.

Notes: Sample targets and acquirers are matched with control firms by industry and firm size. \%Positive is the proportion of positive differences of the total number of non-zero differences. Statistical significance is assessed using a two-tailed Wilcoxon matched-pairs signed-ranks test for the median differences, and a two-tailed Sign test for the percentage of positive differences. 


\section{8 of 23 P. Desyllas and A. Hughes}

matched control. This method allows us to compare the characteristics for 212 couples of acquiring and acquired firms. ${ }^{1}$ Apart from the median difference, the table also reports the proportion of positive differences in the total number of non-zero differences. The null hypothesis of no difference in the distributions between acquiring and acquired firms is tested by the Sign test and the Wilcoxon signed-rank test.

The results suggest that the acquired firms are significantly more $\mathrm{R} \& \mathrm{D}$-intensive than their acquirers. However, this difference disappears once we estimate the median controladjusted difference. This implies that the high R\&D-intensity of targets should be attributed to industry or firm size effects rather than to particular acquisition patterns. The control adjusted comparisons reveal that targets are not different in R\&D-intensity terms from their acquirers. In relation to patent-intensity, there is some evidence that the acquired firms tend to have lower unadjusted and control-adjusted patent-intensity although the median differences are statistically insignificant. However, targets' low patent-intensity becomes economically and statistically significant once patents are expressed in citation-weighted form in both unadjusted and control-adjusted terms. As far as patent stocks are concerned, the results suggest that targets have a significantly smaller unadjusted and control-adjusted patent stock in both raw and citation-weighted form. Therefore, the innovation underperformance of the acquired firms in the immediate pre-acquisition period that has been detected when acquired firms are compared with nonacquired firms, also holds when targets are compared with their acquirers. In fact, targets' innovation underperformance becomes clearer when they are compared with their acquirers. The same is true with targets' poor economic performance. Targets appear to experience significantly slower growth, lower operating returns and Tobin's q in both unadjusted and control-adjusted terms. Results are less clear with respect to leverage and liquidity, except that there is some evidence that targets lack liquidity once industry and firm size effects are accounted for.

\section{Discussion and conclusion}

Despite an extant literature examining the role that acquisitions of entrepreneurial start-ups can play as part of the innovation strategy of large high technology firms (Dushnitsky and Lenox, 2005; Granstrand and Sjolander, 1990; Puranam et al., 2003), our understanding of the innovation-related rationale behind acquisitions that involve large publicly traded firms is surprisingly limited. The main contribution of this paper is the systematic analysis of the innovative profile of the publicly traded firms that are acquired in high technology deals. Although, the results from the analysis suggest that acquisition is a noisy phenomenon and that firm characteristics explain only a modest part of the likelihood of becoming a target, we find evidence that innovation-related variables contribute to the explanation of the acquisition likelihood over and above financial variables that have been employed in the acquisition literature (e.g. Dickerson et al., 2003; Palepu, 1986; Powell, 1997).

The results from our analysis suggest that, in broad terms, although targets tend to be firms with a relatively high $\mathrm{R} \& \mathrm{D}$-intensity and a large patent stock, they are more likely to have a zero or low pre-acquisition patent-intensity compared with non-acquired firms.

1 The 212 deals analysed are deals where both the acquiring and acquired firms are incorporated in the USA and where the required data are available for both firms. The number of deals with data on some of the financial variables (Tobin's q, leverage, liquidity) falls because data on these variables were missing from the matched controls to the sample firms. 
With respect to other target characteristics, we find evidence that targets tend to be somewhat larger than non-acquired firms, and they are relatively more likely to experience poor profitability and low liquidity. The underperformance of the target firms becomes clearer when they are compared with their acquirers. Compared with their acquirers, targets have comparable R\&D-intensity, but a significantly smaller patent stock and significantly lower patent-intensity. Targets also appear to be growing at a slower pace, to have poor growth prospects and to be less profitable compared with their acquirers.

It should be noted that the negative relationship between innovation and economic performance and the likelihood of being acquired has weakened since the mid-1990s, which is a period characterised by a stock market boom. This result is likely to reflect stockmarket related explanations of acquisitions, which have been studied elsewhere in the general acquisition literature (Gugler et al., 2004; Hughes, 1993; Rhodes-Kropf et al., 2005; Shleifer and Vishny, 2001). According to the misvaluation view of acquisitions, acquisition activity is correlated with valuation waves either because in such periods overvalued acquirers can use their stock as a currency to pay for relatively less overvalued targets (Shleifer and Vishny, 2001), or because overall valuation errors are correlated with over-estimation of takeover synergies making it more likely that targets will accept bids (Gort, 1969; Rhodes-Kropf et al., 2005). It appears that the explanatory power of neoclassical views of acquisitions such as the market for corporate control hypothesis-a variation of which has been tested here-weakens during periods of stock market valuation waves (Hughes, 1993; Rhodes-Kropf et al., 2005; Shleifer and Vishny, 2001). ${ }^{1}$

Our findings shed light on the rationale behind acquisitions of public technology firms. We find that targets are more likely to have zero or low patent-intensity before they are acquired relative to non-acquired firms, despite being highly R\&D-intensive. We also find that they have lower patent-intensity relative to their acquirers, despite a comparable R\&Dintensity. These findings are broadly consistent with the 'inferiority' explanation. However, the finding that targets tend to have a large accumulated patent stock (which is calculated over the 6-7 years pre-acquisition) relative to non-acquired firms implies that these firms are acquired when they are underperforming relative to their long run average. It appears that, although targets are indeed actively involved in $R \& D$ and have succeeded in the past in generating innovation output, recent shortfalls in their $R \& D$ pipeline, particularly when accompanied by poor economic performance, turn out to be enough to increase the likelihood of being acquired. It is interesting to notice that our findings are similar to those of another high technology specific US study of Addanki (1986). Despite differences in sample periods, in both studies publicly traded firms acquired are likely to be R\&Dintensive firms without any valuable pre-acquisition patenting activity. These findings also echo studies that focus on financial effects where short-term profitability is found to be a more powerful predictor of takeover than medium- or long-term profits (e.g. Cosh and Hughes, 2008; Hughes, 1993).

Our study has important implications for the acquiring firms' post-acquisition integration strategy. The finding that the acquired firms tend to be innovatively and economically inefficient in the immediate pre-takeover period implies that a key determinant of value creation will be the capability of the acquiring firms' management to transfer successfully their 'superior' capabilities to the acquired business units. In other

\footnotetext{
${ }^{1}$ During such periods alternative acquisition explanations, such as behavioural explanations, seem to outweigh explanations that are based on profit maximisation and market efficiency assumptions (Gugler et al., 2004).
} 


\section{0 of 23 P. Desyllas and A. Hughes}

words, the success of such acquisitions will depend on whether the acquirer deploys its resources and capabilities to address the factors that inhibit the target's recent performance reaching its full potential. The literature on acquisition implementation and integration (Bresman et al., 1999; Capron and Mitchell, 1998; Haspeslagh and Jemison, 1991) suggests that this is a highly complex issue and requires proactive and careful action from the acquiring firm's side.

\section{Bibliography}

Addanki, S. 1986. 'Mergers and Innovation', PhD Thesis, Boston, Harvard University

Agrawal, A. and Jaffe, J. F. 2003. Do takeover targets under-perform? Evidence from operating and stock returns, fournal of Financial and Quantitative Analysis, vol. 38, no. 4, 721-46

Ambrose, B. W. and Megginson, W. L. 1992. The role of asset structure, ownership structure, and takeover defences in determining acquisition likelihood, fournal of Financial and Quantitative Analysis, vol. 27, no. 4, 575-89

Andrade, G. and Stafford, E. 2004. Investigating the economic role of mergers, fournal of Corporate Finance, vol. 10, no. 1, 1-36

Arrow, K. J. 1962. Economic welfare and the allocation of resources for invention, pp. 609-25 in Nelson, R. R. (ed.), The Rate and Direction of Inventive Activity: Economic and Social Factors, Princeton, Princeton University Press

Barber, B. M. and Lyon, J. D. 1996. Detecting abnormal operating performance: The empirical power and specification of test statistics, Fournal of Financial Economics, vol. 41, no. 3, 359-99

Barney, J. B. 1986. Organizational culture: can it be a source of sustained competitive advantage? Academy of Management Review, vol. 11, no. 3, 656-65

Barney, J. B. 1991. Firm resources and sustained competitive advantage, fournal of Management, vol. 17, no. 1, 99-120

Beck, N., Katz, J. N. and Tucker, R. 1997. 'Beyond Ordinary Logit: Taking Time Seriously in Binary Time-Series-Cross-Section Models', Working Paper no. 1017, California Institute of Technology, Social Science

Beshears, J., Choi, J. J., Leibson, D. and Madrian, B. C. 2008. 'How are Preferences Revealed?', NBER Working Paper, no. W13976

Blanchard, O., Lopez-de-Silanes, F. and Shleifer, A. 1994. What do firms do with cash windfalls? fournal of Financial Economics, vol. 36, no. 3, 337-60

Blonigen, B. A. and Taylor, C. T. 2000. R\&D intensity and acquisitions in high-technology industries: Evidence from the US electronic and electrical equipment industries, The fournal of Industrial Economics, vol. XLVIII, no. 1, 47-70

Blundell, R., Bond, S. R., Devereux, M. P. and Schiantarelli, F. 1992. Investment and Tobin's q: Evidence from company panel data, Fournal of Econometrics, vol. 51, no. 1-2, 233-57

Bower, J. L. 2001. Not all M\&As are alike-and that matters, Harvard Business Review, March, 93-101

Bresman, H., Birkinshaw, J. and Nobel, R. 1999. Knowledge transfer in international acquisitions, fournal of International Business Studies, vol. 30, no. 3, 439-62

Capron, L. and Mitchell, W. 1998. Bilateral resource redeployment and capabilities improvement following horizontal acquisitions, Industrial and Corporate Change, vol. 7, no. 3, 453-84

Chakrabarti, A., Hauschildt, J. and Suverkrup, C. 1994. Does it pay to acquire technological firms? RED Management, vol. 24, no. 1, 47-56

Cosh, A., Hughes, A. and Wood, E. 1996. Innovation: scale, objectives and constraints, pp. 51-61 in Cosh, A. and Hughes, A. (eds), The Changing State of British Enterprise: Growth, Innovation and Competitive Advantage in Small and Medium-sized Firms 1986-1995, Cambridge, ESRC Centre for Business Research, University of Cambridge

Cosh, A. D. and Hughes, A. 2008. Takeovers after 'Takeovers', in Arestis, P. and Eatwell, J. (eds), Issues in Finance and Industry, London, Palgrave Macmillan

D’Agostino, R. B., Lee, M.-L., Belanger, A. J., Cupples, L. A., Anderson, K. and Kannel, W. B. 1990. Relation of pooled logistic regression to time dependent cox regression analysis: The framingham heart study, Statistics in Medicine, vol. 9, no. 12, 1501-15 
Danzon, P. M., Epstein, A. and Nicholson, S. 2004. 'Mergers and Acquisitions in the Pharmaceutical and Biotech Industries', NBER Working Paper no. W10536

Desyllas, P. and Hughes, A. 2008. Sourcing technological knowledge through corporate acquisition: evidence from an international sample of high technology firms, The fournal of High Technology Management Research, vol. 18, no. 2, 157-72

Dickerson, A. P., Gibson, H. D. and Tsakalotos, E. 2002. Takeover risk and the market for corporate control: the experience of British firms in the 1970s and the 1980s, International Fournal of Industrial Organization, vol. 20, no. 8, 1167-95

Dickerson, A. P., Gibson, H. D. and Tsakalotos, E. 2003. Is attack the best form of defence? A competing risks analysis of acquisition activity in the UK, Cambridge fournal of Economics, vol. 27 , no. $3,337-57$

Dierickx, I. and Cool, K. 1989. Asset stock accumulation and sustainability of competitive advantage, Management Science, vol. 35, no. 1, 1504-11

Dixit, A. K. and Pindyck, R. S. 1994. Investment Under Uncertainty, Princeton, Princeton University Press

Dushnitsky, G. and Lenox, M. J. 2005. When do firms undertake R\&D by investing in new ventures? Strategic Management fournal, vol. 26, no. 10, 947-65

Eddey, P. H. 1991. Corporate raiders and takeover targets, fournal of Business Finance and Accounting, vol. 18, no. 2, 151-71

Fleming, L. 2001. Recombinant uncertainty in technological search, Management Science, vol. 47, no. 1, 117-32

Francis, J. and Smith, A. 1995. Agency costs and innovation: some empirical evidence, fournal of Accounting and Economics, vol. 19, no. 2-3, 382-409

Franko, L. G. 1989. Global corporate competition: who's winning, who's losing, and the R\&D factor as one reason why, Strategic Management fournal, vol. 10, no. 5, 449-74

Geroski, P., Machin, S. and Van-Reenen, J. 1993. The profitability of innovating firms, Rand Fournal of Economics, vol. 24, no. 2, 198-211

Gort, M. 1969. An economic disturbance theory of mergers, Quarterly fournal of Economics, vol. 83 , no. $4,624-42$

Granstrand, O. and Sjolander, S. 1990. The acquisition of technology and small firms by large firms, Fournal of Economic Behaviour and Organization, vol. 13, no. 3, 367-86

Grant, R. M. 1996. Toward a knowledge-based theory of the firm, Strategic Management Fournal, vol. 17, Winter Special Issue, 109-22

Griliches, Z. 1990. Patent statistics as economic indicators: a survey, fournal of Economic Literature, vol. XXVIII, no. 4, 1661-707

Gugler, K., Mueller, D. C., Yurtoglu, B. and Zulehner, C. 2004. 'The Determinants of Mergers: An International Comparison', mimeo, University of Vienna

Hall, B. H. 1988. The effect of takeover activity on corporate research and development, pp. 69-100 in Auerbach, A. J. (ed.), Corporate Takeovers: Causes and Consequences, Chicago, University of Chicago Press

Hall, B. H. 1990. 'The Manufacturing Sector Master File: 1959-1987', NBER Working Paper no. W3366

Hall, B. H. 1999. Mergers and R\&D revisited, paper presented at the Quasi-Experimental Methods Symposium, Econometrics Laboratory (August), University of California at Berkeley

Hall, B. H. 2000. Innovation and market value, pp. 177-98 in Barrel, R., Mason, G., and O’Mahony, M. (eds), Productivity, Innovation and Economic Performance, Cambridge, Cambridge University Press

Hall, B. H., Jaffe, A. and Trajtenberg, M. 2001. 'The NBER Patent Citations Data File: Lessons, Insights and Methodological Tools' NBER Working Paper no. W8498

Hall, B. H. and Vopel, K. 1996. Innovation, market share, and market value, paper presented at the International Conference on the Economics and Econometrics of Innovation, The European Parliament (June), Strasbourg, France

Hasbrouck, J. 1985. The characteristics of takeover targets: Q and other measures, fournal of Banking and Finance, vol. 9, no. 3, 351-62

Haspeslagh, P. C. and Jemison, D. B. 1991. Managing Acquisitions: Creating Value Through Corporate Renewal, New York, Free Press 


\section{2 of 23 P. Desyllas and A. Hughes}

Hitt, M. A., Hoskisson, R. E., Ireland, D. R. and Harrison, J. S. 1991. Effects of acquisitions on RED inputs and outputs, Academy of Management fournal, vol. 34, no. 3, 639-706

Hitt, M., Hoskisson, R., Johnson, R. A. and Moesel, D. D. 1996. The market for corporate control and firm innovation, Academy of Management fournal, vol. 39, no. 5, 1084-119

Hughes, A. 1993. Mergers and economic performance in the UK: A survey of the empirical evidence 1950-1990, pp. 9-95 in Bishop, M. and Kay, J. (eds), European Mergers and Merger Policy, Oxford, Oxford University Press

Hughes, A., Mueller, D. C. and Singh, A. 1980. Hypotheses about mergers, pp. 27-65 in Mueller, D. C. (ed.), The Determinants and Effects of Mergers, Cambridge, Oelschlager Gunn and Hain

Jensen, M. C. 1986. The takeover controversy: analysis and evidence, Midland Corporate Finance fournal, vol. 4, no. 2, 6-32

Jensen, M. C. and Ruback, R. S. 1983. The market for corporate control: the scientific evidence, fournal of Financial Economics, vol. 11, no. 1-4, 5-50

Kaplan, S. and Zingales, L. 1997. Do financing constraints explain why investment is correlated with cash flow? Quarterly fournal of Economics, vol. 112, no. 1, 169-215

Kim, D. and Kogut, B. 1996. Technological platforms and diversification, Organization Science, vol. 7 , no. 3, 283-301

Kogut, B. and Zander, U. 1992. Knowledge of the firm, combinative capabilities and the replication of technology, Organization Science, vol. 3, no. 3, 383-97

Lee, D. E. 1999. A modified version of the Lewellen and Badrinath measure of Tobin's q, Financial Management, vol. 28, no. 1, 16-36

Manne, H. 1965. Mergers and the market for corporate control, fournal of Political Economy, vol. 73 , no. $2,110-20$

McConnell, J. J. and Martin, K. J. 1991. Corporate performance, corporate takeovers and management turnover, The fournal of Finance, vol. XLVI, no. 2, 671-88

Mitchell, M. L. and Muhlerin, H. J. 1996. The impact of industry shocks on takeovers and restructuring activity, fournal of Financial Economics, vol. 41, no. 2, 193-229

Morck, R., Shleifer, A. and Vishny, R. 1988. Characteristics of targets of hostile and friendly takeovers, pp. 101-29 in Auerbach, A. J. (ed.), Corporate Takeovers: Causes and Consequences, Chicago, Chicago University Press

Morck, R. and Yeung, B. 1992. Internalization: an event study test, fournal of International Economics, vol. 33, no. 1-2, 41-56

Mueller, D. C. 2003. The Corporation. Investment, Mergers and Growth, London, Routledge

Mueller, D. C. and Sirower, M. L. 2003. The causes of mergers: Tests based on the gains to acquiring firms' shareholders and the size of premia, Managerial and Decision Economics, vol. 24, no. 5, 373-91

Palepu, K. G. 1986. Predicting takeover targets: a methodological and empirical analysis, fournal of Accounting and Economics, vol. 8, no. 1, 3-35

Pavitt, K. 2005. Innovation process, pp. 86-114 in Fagerberg, J., Mowery, D. C., and Nelson, R. R. (eds), The Oxford Handbook of Innovation, Oxford, Oxford University Press

Penrose, E. T. 1959. The Theory of the Growth of the Firm, New York, John Wiley

Philippon, T. 2004. 'Revealed Preferences for Corporate Leverage' European Corporate Governance Institute Working Paper Series in Finance, Working Paper no. 36/2004

Powell, R. 1997. Modelling takeover likelihood, fournal of Business, Finance and Accounting, vol. 24, no. 7, 1009-30

Puranam, P., Singh, H. and Zollo, M. 2003. A bird in the hand or two in the bush? Integration trade-offs in technology-grafting acquisitions, European Management Fournal, vol. 21, no. 2, $179-84$

Rhodes-Kropf, M., Robinson, D. T. and Viswanathan, S. 2005. Valuation waves and merger activity: the empirical evidence, Fournal of Financial Economics, vol. 77, no. 3, 561-603

Scherer, F. M. 1997. 'Investing in Technological Innovation', Judge Institute of Management Studies Working Paper no. 08/97

Shleifer, A. and Vishny, R. 2001. 'Stock Market Driven Acquisitions' NBER Working Paper no. W8439

Singh, A. 1975. Takeovers, economic natural selection and the theory of the firm: Evidence from the post war UK experience, Economic fournal, vol. 85, no. 339, 497-515 
Singh, A. 1992. Corporate takeovers, in Eatwell, J., Milgate, M., and Newman, P. (eds), The New Palgrave Dictionary of Money and Finance, London and New York, Macmillan

Teece, D. 1986. Profiting from innovation: implications for integration, collaboration, licensing and public policy, Research Policy, vol. 15, no. 6, 285-305

Teece, D., Pisano, G. P. and Shuen, A. 1997. Dynamic capabilities and strategic management, Strategic Management fournal, vol. 18, no. 7, 509-33

Vermeulen, F. and Barkema, H. 2001. Learning through acquisitions, Academy of Management Fournal, vol. 44, no. 3, 457-76

Wernerfelt, B. 1984. A resource-based view of the firm, Strategic Management fournal, vol. 5, no. $2,171-80$

Williamson, O. E. 1975. Markets and Hierarchies: Analysis and Antitrust Implications, New York, Free Press

Zenger, T. R. 1994. Explaining organisational diseconomies of scale in R\&D: agency problems and allocation of engineering talent, ideas and effort by firm size, Management Science, vol. 40, 708-29 